\title{
Diamond Concept as Principle for the Development of Spinal Cord Scaffold: A Literature Review
}

\author{
Yudha M. Sakti ${ }^{1}$, Rusdy Ghazali Malueka ${ }^{2}$, Ery Kus Dwianingsih ${ }^{3}$ (D), Ahmad Kusumaatmaja ${ }^{4}$ D, Akbar Mafaza ${ }^{1}$, \\ Deas Makalingga Emiri ${ }^{5}$ iD \\ ${ }^{1}$ Department of Surgery, Division of Orthopedics and Traumatology, Faculty of Medicine, Public Health and Nursing, Universitas \\ Gadjah Mada, Dr. Sardjito General Hospital, Yogyakarta, Indonesia; ${ }^{2}$ Department of Neurology, Faculty of Medicine, \\ Public Health and Nursing, Universitas Gadjah Mada, Dr. Sardjito General Hospital, Yogyakarta, Indonesia; ${ }^{3}$ Department \\ of Anatomical Pathology, Faculty of Medicine, Public Health and Nursing, Universitas Gadjah Mada, Dr. Sardjito General \\ Hospital, Yogyakarta, Indonesia; ${ }^{4}$ Department of Physics, Faculty of Mathematics and Natural Science, Universitas Gadjah \\ Mada, Yogyakarta, Indonesia; ${ }^{5}$ Bachelor Student, Faculty of Medicine, Public Health and Nursing, Universitas Gadjah Mada, \\ Yogyakarta, Indonesia
}

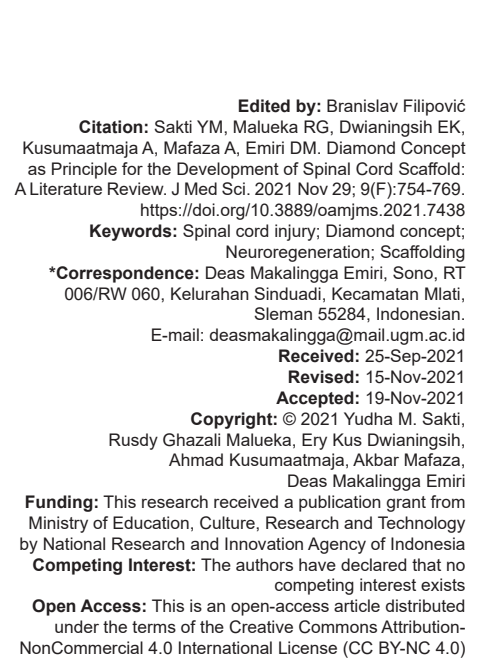

Introduction

Spinal cord injury $(\mathrm{SCl})$ has been bringing a lot of detrimental impacts on the affected individuals. However, not only that, but it also brings a tremendous effect on the socioeconomic and health-care system [1]. By numbers of the incident, $90 \%$ of the cases caused by traumatic incidences. Male individuals are prone to have higher risk due to a higher portion of high-impact activity [1], [2]. Besides that, the case of $\mathrm{SCl}$ gives a pattern of bimodal peak of period: Adolescence due to increasing activity and mobility and elderly due to degenerative process. Both adults and the elderly could have various clinical outcomes ranging from pain to tetraplegia [3]. Previous research on the economic burden of SCI based on hospital charges revealed that it could span from 1.47 million up to 2.34 million dollars but vary due to the various socioeconomic disadvantage of a patient [4], [5].
Treatment regimen and strategy for $\mathrm{SCl}$ patient have been continually researched. Differ with injury in peripheral nerve system, $\mathrm{SCl}$ gives a challenging obstacle for any clinician to improve patient neurologic function. Spinal cord acts as the main neuronal pathway that connects brain into human organ or vice versa. Moreover, regeneration of neuronal structure and connection of injured spinal cord is physiologically impossible and remarkably difficult to modified [6]. The main obstacles of regeneration on neuronal structure are neuroinflammatory process that along with poor debris clearance which causing a longer time for healing process and give an extensive process of inflammation. Due to this certain inflammatory process, human body reacts by limiting the extension of inflammation with purpose to maintain the healthy tissue. Its reaction conducted by two mechanisms: Microglia bordering on perilesional site and glial scar on the injury site [7]. Those phenomena occur alongside with the production inhibitory growth 
factor. All of those reactions supposed to be beneficial by supporting debris clearance but on the other hand, it also compromises the regeneration process. Existence of glial scar and inhibitory growth factor significantly suppresses the capability of axonal regeneration. While no regeneration of neuronal structure occurs, injury site will remain in the form of cystic cavity without any function structure inside it [1], [7].

To resolve all of the mentioned major issues in the neuronal regeneration of $\mathrm{SCl}$, comprehensive model is necessary to analyze each step of progressive condition in SCl. Many of the previous study on regenerative attempts of $\mathrm{SCl}$ have concluded that to gain optimal outcome, combination of various aspects in the treatment regimen is mandatory. Complex milieu such as $\mathrm{SCl}$ problem will need a complex analysis and approach. Previously, a regenerative concept of view to understand the requirement of post-injury rehabilitation has been introduction in the field of orthopedic, especially for fracture trauma. This concept called "Diamond Concept" which consists of osteogenicity as the cellular platform, osteoinductivity as the supportive criteria for cellular activity, osteoconductivity as residence for related cell, and mechanical strength to support mechanic-environmental stability [8], [9].

Cellular platform portrays the ideal condition of a cell to undergo biological activity. This condition includes the absence of any insult toward cellular environment that causing detrimental effect on the cell. In any identified cell in human body, all of them are working to maintain homeostasis state of a tissue which then gives a bigger effect on organ and system homeostasis. To gain homeostasis state, cell must able to do a proper cellular transport [10], maintain the membrane cell integrity [11] and protein synthesis process [12]. Absence of cellular structure would not create homeostatic condition or even functional tissue.

Cellular inductivity is a requirement where the condition of extracellular should support cellular activity. Each cell has different roles that may have effect on each other. To build a system, each component should support on each other to reach a certain homeostatic goal. For example, SCl condition will involve many cells which its own contribution. Each of adjacent cells will communicate whether using signaling pathway of cytokine or growth factor [13]. Those media of cellular communication will be received by surface protein receptor on cell membrane. Processed signal will result a certain effect on the cell. Pro- inflammatory signal will result apoptosis of cell, anti-inflammatory signal will increase cellular survival, and regenerative signal will result higher cellular activity for structural rebuilding include also the differentiation process as the part of regeneration [14].

Cellular conductivity is related to supportive residence for cell to take place the activity. Each cell needs a certain supportive microenvironment to support the activity. Especially stem cell, to differentiate into a mature and specific cell, it needs a certain surface to act as host. This surface of material could be and endogenous matrix which produces by human body or also implanted exogenous matrix. Both either endogenous or exogenous matrix should able to facilitate cell migration and adhesion. Without the capability to host cellular development, any intervention won't be able to support regeneration process [15]. The previous study has also proposed that well-designed matrix will directly cellular sustainability and differentiation lineage [16].

Structural integrity or mechanic environmental stability are closely related with physical pressure towards a structure. Basically, applied pressure will automatically change structural formation either transiently or permanently. The previous studies had come up with a result that either absence, micro or macro movement could affect regeneration process [8]. Another part of structural integrity is gap filling. Necrotic tissue should be replaced by regenerative process. However, during the process, those gaps that exist between healthy tissues could result structural instability. Implantation of any available matrix to fill the gap could give mechanical stability enhancement [17].

Recent research has been purposed to develop a treatment strategy of $\mathrm{SCl}$ using spinal scaffold to improve the patient outcome. Spinal scaffold has the flexibility to be combined with another treatment method such as neuroprotective or neuroregenerative or both in one intervention as utilization of spinal scaffold includes drug delivery system [18]. Consideration of using scaffold in treatment of $\mathrm{SCl}$ is also it capability to replace extensive spinal cord tissue damage and also facilitates the host of stem cell treatment with modifiable tissue growth environment. By that, growth of implanted stem cell could be guided for appropriate development of new axonal structure [19].

Treatment involving spinal scaffold has reach into a clinical trial, but the treatment strategy to reach the most efficient outcome is not yet to be defined. The implantation of scaffold in $\mathrm{SCl}$ has been challenging but yet promising as within a decade, there is an improvement prognosis for $\mathrm{SCl}$ patient. In this review, we would like to redefine a comprehensive concept of "Diamond Concept" from previously used for fracture management into SCI management. This comprehensive concept will also include the perspective of material selection and combination of other treatment and procedure such as stem cell seeding and growth factor or drug involvement.

\section{Discussion}

\section{$\mathrm{SCl}$ in the perspective of diamond concept}

An abrupt, severe impact on the spine that fractures or dislocates vertebrae is the most prevalent 
cause of SCI. Primary damage occurs when "displaced bone fragments, disc materials, and/or ligaments bruise or tear into the spinal cord tissue" during the initial mechanical stresses imparted to the spinal cord at the time of injury. Notably, most injuries do not completely damage the spinal cord. Four main characteristic mechanisms of primary injury have been identified. From the most common form of primary injury is impact plus persistent compression, impact alone with transient compression, distraction injuries occur when two adjacent vertebrae are pulled apart causing the spinal column to stretch, and laceration or transection by direct particle hit to the spinal cord injuries [1], [2].

Secondary injury begins within minutes following the initial primary injury and continues for weeks or months causing progressive damage of spinal cord tissue surrounding the lesion site. It can be temporally divided into acute, subacute and chronic phases. Those events following the primary injury are presented in the Table 1:

Table 1: Events following primary injury of $\mathrm{SCl}$

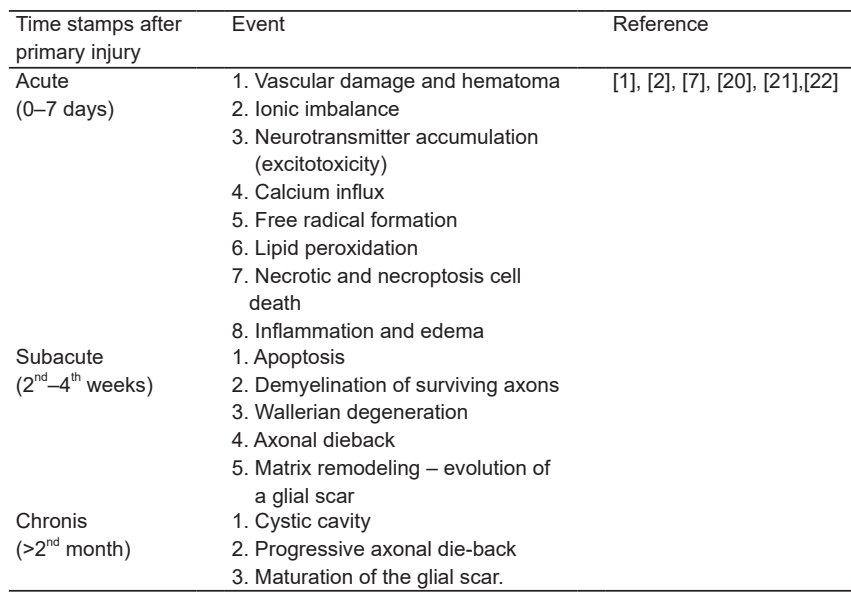

\section{Cellular platform}

Injured spinal cord after direct physical insult will causing a compromise of structural integrity of the related tissue. Due to the presence of compressing structures such as fracture debris or a herniated nucleus, it creates an unfavorable environment for cells to survive moreover direct impact to the cell may cause membrane damage and leading to cell death. The early effects after direct physical insult are the disruption of spinal cord vascular supply and hypoperfusion [21], [22]. By that, those two conditions will lead into neurogenic shock as the result of impaired perfusion of spinal cord and extravasation of leukocytes and red blood cells will occur due to disrupted vascular structure and will causing edema. Increasing tissue pressure due to edema will later induce vasospasm on intact vessels and the compromising collateral blood flow to the spinal cord [21].

Cellular damage and hypoxia due to vascular disruption will lead into significant rise of glutamate, the main excitatory neurotransmitter in the central nerve. Exposure of intracellular constituent due to cellular damage and necrosis triggers this increment. Free glutamate in the extracellular will induce excitotoxicity by igniting $\mathrm{N}$-methyl-d-aspartate (NMDA) receptor. Overactivity of NMDA receptor on the neurons will be causing mitochondrial calcium overload. Mitochondrial calcium overload will activate nicotinamide adenine dinucleotide phosphate oxidase and induce the generation of superoxide [23]. This process will result reactive oxygen species (ROS) and reactive nitrogen species (RNS). Both materials activate cytosolic poly (ADP-ribose) polymerase and will be leading to failure of glycolysis and depletion of ATP. Moreover, ROS and RNS could freely bind to any organelle inside the cell. The most detrimental effect will occur if it binds the lipid structure in membrane cell and amino acid structure. When reactive materials react with polyunsaturated fatty acids in the cell membrane, it will create free superoxide radicals and compromising membrane integrity and also if it reacts with amino acid structure such as DNA, it will cause defect of DNA expression the ultimately leading to cell death. Since NMDA receptors are spread widely over the neurons, various cell could be the subject of this cascade such as astrocytes, oligodendrocytes, and myelin in white matters [24], [25].

\section{Cellular inductivity}

Cellular platform disturbance can lead to cell death in the process of necrosis by direct severe impact to the cell or biochemical disturbance due to nutrient and oxygen deprivation. However, some of the healthy cell around the site of injury could also undergo a necrotic process without having any of mentioned above. These phenomena are called necroptosis or a programmed cell death [26]. Necroptosis is a receptormediated process. It is induced downstream of the TNF receptor 1 (TNFR1) and is dependent on the activity of the receptor interacting protein kinase 1 and 3 (RIPK1 and RIPK3). Necroptosis has the similar morphological characteristics as necrosis [26], [27].

Another cell death mechanism that has been studied the most in $\mathrm{SCl}$ is apoptosis. This process takes place in cells that survive the primary injury but endures enough insult to activate their apoptotic pathways [28]. Apoptosis typically occurs in a delayed manner in areas more distant to the injury site and most abundantly affects oligodendrocytes, microglia, and astrocytes. It happens as within $4 \mathrm{~h}$ after primary injury and peaks within 7 days. Apoptosis is induced by activation of death receptors such as FAS and TNFR1, which eventually activates caspase 8 and imbalance of intracellular pro- and anti-apoptotic proteins [29], [30].

In $\mathrm{SCl}$, the induction of the inflammatory process is also a significant event. Secondary injury pathways include neuroinflammation, which has both local and systemic implications. Neutrophils, local 
microglia, and astrocytes, as well as dendritic cells, blood-borne macrophages, and B- and T-lymphocytes, are all implicated in the inflammatory response after injury [31]. The recruitment of innate inflammatory cells occurs in the early phase of inflammation (0-2 days after damage). The adaptive inflammatory cell is involved in the second phase of inflammation, which begins 3 days after the injury [32]. Antibody production triggers humoral inflammation, which activates phagocytes, aggravating neuroinflammation, and causing tissue death [31], [33].

\section{Cellular conductivity}

Traumatic SCl causes glial scar tissue to develop around the injury epicenter. The glial scar is a multifactorial phenomenon that involves activated astrocytes, NG2+ oligodendrocyte precursor cells (OPCs), microglia, fibroblasts, and pericytes, among other populations in the damaged spinal cord [34], [35]. The astrocytic glial scar has been demonstrated to act as a protective barrier, preventing immune cells from spreading into neighboring segments. Despite its protective effect in acute $\mathrm{SCl}$, the astrocytic glial scar's evolution and persistence in the subacute and chronic stages of injury have been deemed a significant inhibitor of spinal cord repair and regeneration. Chondroitin sulfate proteoglycans are well-known for their roles for inhibiting axonal regeneration, sprouting, conduction, and remyelination by the glial scar and difficult to be modified due to dual role of benefit and harm. It has been the most challenging factor in therapeutic purpose [36], [37].

\section{Structural integrity}

When the spinal cord is injured, the body responds by cleaning and repairing itself. The cleaning process will be carried out by an inflammatory reaction, while the healing phase will be carried out by the regeneration process. However, due to the presence of numerous inhibitory variables, none of these processes are optimal. The presence of a glial scar results in a minimal amount of regenerative activity to repair the damaged component. Complications may arise after a long period of $\mathrm{SCl}$. One of these is the glial scar that prevents the formation regenerative structure and leaving a cyst in the spinal cord. This cyst is filling the hole left by the injury, which should be filled by a new neural structure. The pathogenesis of this phenomenon is uncertain and still under investigation. Filling this cavity space is challenging for bridging support to neuronal structure, especially axon.

\section{Time window for SCl treatment}

Several various time limits have been employed to define "early" versus "late" surgical decompression in clinical investigations; the variability of definitions has made it difficult to draw firm conclusions about the ideal timing of surgical intervention. The first $24 \mathrm{~h}$ after the injury still considered as the golden periods for deploying surgical decompression. However, there is still no legit evidence to exactly date the time of decompression between early and later relative to $24 \mathrm{~h}$ threshold. According to the current guideline, there was Class II evidence to support (1) that early surgery $(72 \mathrm{~h}$ ) can be performed safely in patients with $\mathrm{SCl}$ if they have hemodynamic optimization, and (2) a recommendation for urgent reduction in bilateral locked facets in patients with incomplete tetraplegia, and (3) a recommendation for urgent decompression in patients with $\mathrm{SCl}$ with neurologic deterioration [38]. Current guideline of acute $\mathrm{SCl}$ still recommending for delivery of high-dose methylprednisolone with $8 \mathrm{~h}$ of time after $\mathrm{SCl}$ incident [39].

Scaffolding theoretically effective if given strategy is deployed within acute time frame of SCl. Many of previous in vivo report in scaffolding with $\mathrm{SCl}$ models have shown an advantageous evidence of antiinflammatory effect and neuroregenerative outcome. However, in terms of human implantation, those theories are not yet able to be proved. Current scaffolding report that involves human in the experiment is only in timeframe of chronic phase due to the limitation of technology to distinct necrotic and healthy spinal cord tissue within acute and subacute period of injury. There is a substantial need to address this time window issue for scaffolding [40], [41], [42].

\section{Diamond concept as principle for the development of spinal cord scaffold}

\section{Cellular platform}

Major challenge in developing spinal scaffold for $\mathrm{SCl}$ treatment is to create a platform for a cell that supports its bioactivity for cellular sustainability. The material selection and design processing have the most role in this part [17]. The material of a scaffold contains various chemical structures either natural or synthetic. Those material structures will directly interact with adjacent structure of implantation site and may cause cellular environmental change [43]. Due to neuroinflammation process on the site of injury, cellular structure of a neuron is severely damaged. Implantation of a scaffold would not hold the process of necrosis, necroptosis, and apoptosis. The purpose of providing a cellular platform for the regeneration process is to encourage new differentiated cells derived from stem cell seeding while also preventing or inhibiting inflammatory cell activity from forming scars around the implant, which could hinder any neural structure repair [19].

Given the substantial loss of neural cells following $\mathrm{SCl}$, repopulating cells that are not replenished by the endogenous regenerative process with various 
types of cells transplanted into the wounded spinal cord are an obvious option for treating $\mathrm{SCl}$. When it comes to stem cell therapy, the presence of a scaffold is extremely useful [17]. Without a cellular platform to support cell activity, implanted stem cells may face challenges such as low seeded cell survival rates after transplantation into the injured spinal cord, seeded cell retention at the lesion site without migration, and irregularly filling the lesion cavity, which can lead to axonal growth that is guided randomly [18].

During the regeneration process, oligodendrocytes and astrocytes produced from stem cell implantation play an important role. By forming myelin around signal transducing axons, oligodendrocytes aid in the restoration of normal central nervous system (CNS) function. While astrocytes regulate synaptogenesis, neurotransmission, metabolic support, and the establishment and maintenance of the blood-brain barrier (BBB), they also perform a variety of other roles in normal CNS physiology. Both cells are the main nurturing cell to develop axonal regeneration from proximal to caudal site of injury [44].

Oligodendrocytes and astrocytes derived from stem cell implantation take a substantial role during the regeneration process. Oligodendrocytes help to restore normal function to the CNS through formation of myelin around signal transducing axons, while astrocytes play diverse and crucial roles in normal CNS physiology, regulating synaptogenesis, neurotransmission, metabolic support, BBB formation/ maintenance. Both cells are the main nurturing cell to develop axonal regeneration from proximal to caudal site of injury [45].

There have been a lot of stem cell selection to be used in the therapy of SCl. Between them, embryonic stem cell (ESC), bone marrow mesenchymal stem cell (BMSC), and neural stem/progenitor cell (NSPC) have been widely researched for regenerative strategy. Below we discuss the comparison between available stem cells.

\section{ESC}

Through stem cell banking or therapeutic cloning, ESC could allow for the synthesis of typematched tissues for each patient. Because ESC can be cultured for long periods of time, they can potentially provide huge volumes of cells for tissues that cannot be obtained directly from a tissue source [46]. The ability to guide the differentiation of stem cells into desired tissue lineages is thus one of the important milestones in ESC use for regenerative medicine [47]. Required criteria for ESC in stem cell therapy are capable of prolonged undifferentiated proliferation in culture, exhibit and main normal diploid karyotype, pluripotent, express high level of OCT 4 and Nanog, remain in $s$ phase of cell during their life span, and can be induced to differentiate after continuous of culture [47]. Brief explanation of embryonal stem cell application presented in Table 2.

Table 2: Embryonal stem cell application

\begin{tabular}{|c|c|c|c|}
\hline Stem cell & Preparation & Mechanism & Effectivity \\
\hline $\begin{array}{l}\text { Embryonal } \\
\text { stem cell }\end{array}$ & $\begin{array}{l}\text { - Isolation of human } \\
\text { embryonal stem } \\
\text { cells from human } \\
\text { embryo inner cell } \\
\text { mass. } \\
\text { - Culturing human } \\
\text { embryonal stem } \\
\text { cells in the } \\
\text { medium containing } \\
\text { fibronectin and } \\
\text { laminin } \\
\text { - Differentiating } \\
\text { human embryonal } \\
\text { stem cells into } \\
\text { required lineage. } \\
\text { Addition of } \\
\text { retinoic acid and } \\
\text { nerve growth } \\
\text { factor will induce } \\
\text { differentiation into } \\
\text { functional neurons } \\
\text { - In vitro and in vivo } \\
\text { testing }\end{array}$ & $\begin{array}{l}\text { - Human embryonic } \\
\text { stem cell-derived } \\
\text { oligodendrocytes } \\
\text { or oligodendrocyte } \\
\text { progenitor cells } \\
\text { and motoneuron } \\
\text { progenitors enhance } \\
\text { astrogliosis and } \\
\text { promote motor } \\
\text { recovery [48]. } \\
\text { - ESC-derived neural } \\
\text { lineage cells enable } \\
\text { axons to pass through } \\
\text { chondroitin sulfate } \\
\text { proteoglycan (CSPG), } \\
\text { which is a tremendous } \\
\text { barrier to axonal[49] } \\
\text { regeneration. } \\
\text { - ESC-derived OPC } \\
\text { expresses neurotrophic } \\
\text { factors such as neurite } \\
\text { growth-promoting } \\
\text { factor } 2 \text { (NEGF2), } \\
\text { hepatocyte growth } \\
\text { factor (HGF), activin } \\
\text { A, transforming growth } \\
\text { factor-beta } 2 \text { (TGF- } \beta 2 \text { ), } \\
\text { and brain-derived } \\
\text { neurotrophic factor } \\
\text { (BDNF), providing } \\
\text { significant therapeutic } \\
\text { effects in SCl such as } \\
\text { neuronal survival and } \\
\text { neurite extension [50] }\end{array}$ & $\begin{array}{l}\text { - Significant functional, } \\
\text { legal, and ethical } \\
\text { shortcomings, } \\
\text { however, have limited } \\
\text { the application of } \\
\text { ESCs in human } \\
\text { SCI [50]. } \\
\text { - Shroff reported in } \\
\text { their study of five SCI } \\
\text { patients with Grade } \\
\text { A ASIA score. Two of } \\
\text { the patients showed } \\
\text { improvement from A to } \\
\text { B, one of the patient } \\
\text { from A to C, and two } \\
\text { other patients showed } \\
\text { improvement of bowel } \\
\text { and bladder control but } \\
\text { still remain in Grade } \\
\text { A ASIA score [51]. } \\
\text { It also reported that } \\
\text { delivery of embryonal } \\
\text { stem is effective at the } \\
\text { first phase treatment. } \\
\text { Continuation of } \\
\text { treatment has not } \\
\text { given a significant } \\
\text { result as the first } \\
\text { phase [52]. } \\
\text { - Further clinical } \\
\text { trials are still under } \\
\text { progress to gain more } \\
\text { understanding of } \\
\text { embryonic stem cell. }\end{array}$ \\
\hline
\end{tabular}

\section{BMSC}

BMSCs are a common cell type employed in transplantation studies because they can be easily identified from bone marrow aspiration and grown in culture, allowing for autologous transplantation. BMSCs have also been shown to develop into microglia, oligodendrocytes, and macrophages when transplanted into the spinal cord, in addition to well known number of mesodermal lines [53], [54]. Brief explanation on BMSC application is presented on Table 3 .

Table 3: Bone marrow mesenchymal stem cell application

\begin{tabular}{|c|c|c|c|}
\hline Stem Cell & Preparation & Mechanism & Effectivity \\
\hline $\begin{array}{l}\text { Bone marrow } \\
\text { mesenchymal } \\
\text { stem cell }\end{array}$ & $\begin{array}{l}\text { - Extracted from donor's posterior iliac crest } \\
\text { - Isolated under aseptic condition } \\
\text {-Separated from buffy coat by centrifugation } \\
\text { - Cultured under appropriate medium } \\
\text { - Adherence to standard culture medium } \\
\text { - Positive for CD105, CD73, and CD90 marker } \\
\text { expression } \\
\text { - Negative for CD45, CD34, CD14 or CD11b, } \\
\text { CD 19, HLA-DR }\end{array}$ & $\begin{array}{l}\text { - Producing extracellular matrix (ECM) component } \\
\text { for axon structural support during regeneration } \\
\text { - BM-MSCs demonstrate anti-inflammatory } \\
\text { properties by producing immunoregulatory } \\
\text { cytokines } \\
\text { - Genetic engineering potential of BM-MSCs is an } \\
\text { encouraging method to enhance their therapeutic } \\
\text { effect, such as the regulation of specific factors or } \\
\text { proteins. }\end{array}$ & $\begin{array}{l}\text { - Karamouzine et al.[45] administered BMSCs into } 11 \\
\text { patients with AIS Grade A and found that } 5 / 11 \text { patients } \\
\text { have their AIS grade improved to } C \text {, but the result was } \\
\text { statistically borderline }(P=0.095) \text {. (Karamouzine) } \\
\text { - Mendonca et al.[48] found improvement in AIS grade } \\
\text { from A to B in } 6 / 12 \text { patients and from A to } C \text { in one } \\
\text { patient. }\end{array}$ \\
\hline
\end{tabular}


Table 4: Neural stem/progenitor cell application

\begin{tabular}{|c|c|c|c|}
\hline Stem cell & Preparation & Mechanism & Effectivity \\
\hline $\begin{array}{l}\text { Neural stem/ } \\
\text { progenitor cell } \\
\text { (NSPC) }\end{array}$ & $\begin{array}{l}\text { - Isolation from the source of NSPC. Source of this } \\
\text { stem cell could be acquired from primary isolation } \\
\text { of fetal and adult central nerve system tissue, } \\
\text { deriving differentiation form pluripotent cell or } \\
\text { trans-differentiation from somatic cell. } \\
\text { - Characterization of neural stem cell based on stem } \\
\text { cell markers: Nestin, Sox-2, Musashi, } \beta \text { III-tubulin, } \\
\text { GFAP, and O1. } \\
\text { - Culturing neuronal stem/progenitor cell in neurosphere } \\
\text { and monolayer culture }\end{array}$ & $\begin{array}{l}\text { - NSPC transplantation increased } \\
\text { the expression of NGF, CNTF, } \\
\text { BDNF, IGF-1, and GDNF, which are } \\
\text { advantageous for SCl recovery. } \\
\text { - NSPCs also modulate the inflammatory } \\
\text { response through inhibition of the } \\
\text { secretion of reactive macrophages and } \\
\text { T cells and neuroprotective cytokines. }\end{array}$ & $\begin{array}{l}\text { - Shin reported in the transplantation of human fetal } \\
\text { brain-derived neural stem/progenitor cell } 19 \text { traumatic } \\
\text { cervical spinal cord injury. Five of the patient showed ASIA } \\
\text { score improvement where two from A to C, one from A to B, } \\
\text { and two from B to D. } \\
\text { - Many previous studies have shown a very minimum side } \\
\text { effect after implantation and well tolerable of acceptance. } \\
\text { - Levi reported in patient with subacute and chronic SCI. } \\
\text { NSPC transplantation did not improve ASIA score but give } \\
\text { improvement in motor assessment } \\
\text { - Improvement of outcome for SCI patient with NSPC } \\
\text { transplantation strategy is still under a lot of research. }\end{array}$ \\
\hline
\end{tabular}

\section{NSPC}

This type of cells is pluripotent cells that are isolated from the subventricular region of the ventricles and hippocampus of the brain and the ependymal region of the central canal of the spinal cord. Another source of this cell is human ESC or induced pluripotent cell that differentiated into NSPC and somatic cells that transdifferentiated into NSPC. These cells are capable of differentiating into specific neuronal or glial cells primarily oligodendrocytes, enhancing remyelination, and providing nutritional support, which makes them suitable for cell transplantation therapy in SCI [49]. Brief explanation on NSPC application is presented on Table 4.

\section{Neuroinductivity}

Matrix proteins, growth factors, cytokines, enzymes, and antibodies, among other biologically active substances, have been used to reduce inflammation and improve regeneration following SCl. Non-biologic pharmacological drugs, such as methylprednisolone and dexamethasone, have been used to decrease the immune response systemically and have been reviewed frequently [55]. Modulating the immune response at the site of $\mathrm{SCl}$ to create a more anti-inflammatory phenotype among immune cells improves regeneration capability [56]. The role of immune cells in producing a microenvironment prepared for regeneration has been demonstrated by neutrophil and macrophage depletion experiments that increased damage after $\mathrm{SCl}$, revealing the role of immune cells in generating a milieu prepared for regeneration [57], [58].

A variety of local and systemic delivery tactics has been used to regulate the immune response with physiologically active substances to assure a more regenerative immune cell phenotype. With the purpose of fostering an anti-inflammatory environment, these compounds can be employed to target specific events or cell populations within each step of the inflammatory response [59]. Well-documented report has also shown that precise timing on one or more specific phase of inflammation phase to give the intervention with those biologically active materials could limit secondary injury and promote regeneration [60].

While biologically active compounds have the potential to modulate the inflammatory environment, they breakdown quickly, decreasing their bioavailability. These issues can be solved using more robust molecules, including a delivery vehicle, or taking into account the timing and location of distribution that must be designed specifically for biologic materials. Based on the function of anti-inflammatory substance, the following Table 5 will explore therapeutic options for protection of structural neuron from destructive neuroinflammation process.

Table 5: Neuroprotective agent effect

\begin{tabular}{|c|c|}
\hline $\begin{array}{l}\text { Neuroprotective } \\
\text { agent }\end{array}$ & Therapeutic effect \\
\hline Methylprednisolone & $\begin{array}{l}\text { MP minimized secondary damage by reducing the } \\
\text { injury-induced free radical catalyzed lipid peroxidation in spinal } \\
\text { cord tissue. In addition, it was thought to facilitate neuronal } \\
\text { excitability and impulse conduction and to improve blood flow } \\
\text { through the injured cord [18] }\end{array}$ \\
\hline Nimodipine & $\begin{array}{l}\text { Calcium channel blockers were shown to improve blood flow } \\
\text { to the injured spinal cord. Sustaining blood flow during injury is } \\
\text { important to minimize cell death and secondary injury cascade. } \\
\text { Recent report revealed that nimodipine delivery could prevent } \\
\text { the development of spasticity in vivo [61]. }\end{array}$ \\
\hline GABA agonist & $\begin{array}{l}\text { GABA indirectly gives neuroprotective effect by increasing } \\
\text { excitatory threshold to deliver nociceptive pain signal. This } \\
\text { therapeutic effect will relieve patient sensation of pain during } \\
\mathrm{SCl} \text { management [62]. }\end{array}$ \\
\hline Minocycline & $\begin{array}{l}\text { It has been shown to target multiple secondary injury } \\
\text { mechanisms in spinal cord injury, through inhibiting calcium } \\
\text { influx through the N-methyl-D-aspartate (NMDA) receptors, } \\
\text { mitochondrial calcium uptake, poly (ADP-ribose) polymerase-1 } \\
\text { (PARP-1) enzymatic activity, and iron toxicity [18], [63]. }\end{array}$ \\
\hline $\begin{array}{l}\text { NGF } \\
\text { (neuron growth } \\
\text { factor) }\end{array}$ & $\begin{array}{l}\text { NGF administration improved the motor function recovery and } \\
\text { increased the neurons survival in the spinal cord lesions of } \\
\text { the model rats. NGF decreases neuron apoptosis by inhibiting } \\
\text { activation of caspase- } 3 \text { cascade. It also inhibits caspase } 12 \\
\text { activation and endoplasmic reticulum stress-induced apoptosis } \\
\text { [64], [65] }\end{array}$ \\
\hline $\begin{array}{l}\text { Hepatocyte growth } \\
\text { factor }\end{array}$ & $\begin{array}{l}\text { HGF reduces the formation of glial scar and promotes } \\
\text { functional recovery in animal } \mathrm{SCl} \text { models and has reached } \\
\text { clinical trial in human with positive result[66] }\end{array}$ \\
\hline
\end{tabular}

In the development and repair of the CNS, growth factors play a crucial regulatory role. Another key element causing problems in nerve regeneration after $\mathrm{SCl}$ is a lack of endogenous GFs secretion and production. Exogenous GF supplementation will thus considerably aid SCI healing. However, because of its short half-life in the body, it must be given repeatedly, and intramuscular injections are difficult to pass through the blood-spinal cord barrier. Moreover, they do not improve local drug concentration in the damaged area, so their use in the field of $\mathrm{SCl}$ repair is severely limited [18], [19]. Engineering three-dimensional (3D) stents have emerged as a promising option in this area. Engineering 3D stents have emerged as a promising option in this area. In addition to mixing 3D scaffolds with transfected stem cells, as mentioned above, directly mixing GFs to generate functional engineering 
3D scaffolds have shown to be beneficial [67], [68], [69]. The following Table 6 is well-established growth factor as the part of neuroregenerative factor which already well documented for its therapeutic effect.

Table 6: Neuroregenerative agent effect

\begin{tabular}{|c|c|}
\hline Neuroregenerative agent & Therapeutic effect \\
\hline $\begin{array}{l}\text { NT-3 } \\
\text { (neurotrophin-3) }\end{array}$ & $\begin{array}{l}\text { NT-3 supports survival, growth, and differentiation } \\
\text { of neurons, and it encourages formation of neuronal } \\
\text { synapses [64]. }\end{array}$ \\
\hline $\begin{array}{l}\text { FGF } \\
\text { (fibroblast growth factor) }\end{array}$ & $\begin{array}{l}\text { Stimulated neurotransmitter (Rab-GDI) and restrained } \\
\text { inhibitor (RKIP) of the Raf/MEK/ERK pathway to create } \\
\text { favorable conditions for the regeneration process of } \\
\text { neurons } \\
\text { Clinical trials on chronic SCI have shown the improvement } \\
\text { of the patient condition [70], [71]. }\end{array}$ \\
\hline $\begin{array}{l}\text { BDNF } \\
\text { (brain-derived } \\
\text { neurotrophic factor) }\end{array}$ & $\begin{array}{l}\text { BDNF can enhance regeneration and sprouting of injured } \\
\text { axons in the spinal cord or increased remyelination } \\
\text { of injured axons. BDNF induces the upregulation } \\
\text { of growth-associated genes such as GAP-43 and } \\
\text { T-alpha-1-tubulin in neurons which enhancing } \\
\text { neuroregeneration [64] }\end{array}$ \\
\hline $\begin{array}{l}\text { GDNF } \\
\text { (glial-derived } \\
\text { neurotrophic factor) }\end{array}$ & $\begin{array}{l}\text { GDNF has been shown to regenerate axons, increase } \\
\text { total axonal surface area, increase axon density, and also } \\
\text { significantly increase blood vessels at the injury site [72]. }\end{array}$ \\
\hline
\end{tabular}

\section{Neuroconductivity}

Adult neurons in the CNS have a restricted ability for regeneration due to a neuroinhibitory milieu that prevents endogenous regeneration. Approaching biomaterial strategy could give more option of strategy by designing a material that leads physical guiding, cell infiltration to produce regeneration factors, and mitigation of inhibitory by-products of primary and secondary damage [18], [19].

Biomaterial scaffolds' macroarchitecture aids wound healing by acting as a framework for cell infiltration and remodeling, as well as modifying the immune response. Cellular infiltration inside a porous material network allows for host tissue integration, which decreases cavitation and glial scarring. The absence of considerable cyst formation after spinal cord bridge implantation in highly porous or open designs indicates that the introduction of a scaffold significantly reduces immune cell infiltration while replacing cavitation and the thick glial scar with regenerating tissue [72].

At the microstructural level, biomaterial scaffolds must be permissive to cellular infiltration, biomolecule diffusion, and vascular infiltration to promote and sustain regeneration. Pores, grooves, and fibrous structure are used to generate these features, which can have a significant impact on the immunological response. Porosity enables for scaffold vascularization, changes cell migration into and around the scaffold change cellular phenotypic into regenerative function cell, and increases tissue-implant interface implant stability [43]. Larger pore size has been demonstrated to change macrophage phenotype, causing the population of macrophages to shift to the M2 phenotype. M2 phenotype of macrophage is well known for the opposite of inflammatory M1 phenotype. M2 macrophage has the main role for regenerative purpose in tissue healing [73].
Porosity allows for scaffold vascularization, alters cell migration and phenotype into and around the scaffold, and improves implant stability at the tissueimplant interface. Larger pore size has been shown to alter macrophage phenotype, pushing macrophage population toward an M2 phenotype. While the smaller supports greater vascular infiltration [73], both pore sizes reduced the inflammatory response by reduction foreign body giant cell (FGBC) and promoted healing. While the smaller pore size allows for more vascular infiltration, both hole sizes lowered the inflammatory response and facilitated healing by reducing FGBC [74].

Although it can be difficult to distinguish nanotopography effects from changes in surface chemistry since the two can be intertwined, both nanoscale surface characteristics and chemistry can affect immune cell activity and migratory patterns. The severity of the ensuing inflammation is highly dependent on the biochemical properties of the material and how it denatures adsorbed inflammatory proteins. The degree of hydrophilicity/hydrophobicity is particularly important as hydrophobic materials are more likely to denature adsorbed proteins and are associated with decreased monocyte adhesion as well as decreased macrophage adhesion and FBGC formation in vitro. Hydrophobic materials are more likely to denature adsorbed proteins and are related with lower monocyte adherence as well as decreased macrophage adherence and FBGC production in vitro [18], [19].

Biomatrices must allow regrowing axons to penetrate, grow through, and then exit the matrix. Defining the most appropriate method to induce axonal growth out of the implanted scaffold to form "normal" spinal cord tissue beyond the injury and perhaps allowing axons to reconnect with neuron in the specific target location will be a huge challenge. This might entail not only changing the CNS environment in some way but also being able to adjust the growth-supporting systems within the bridges themselves on a temporal basis [18], [19], [75], [76].

\section{Structural integrity}

Mechanical qualities of scaffolds and structural changes that occur during degradation are important concerns when constructing biomaterial scaffolds for the spinal cord. Scaffolds must have matched stiffness to mirror the rigidity of the nerves while still being sturdy enough not to collapse and hinder nerve regeneration. When biomaterial scaffolds are implanted in vivo, deterioration, recurrent compression from movement, and immune cell-related breakdown and clearance can all shorten their lifespan and lead to graft failure if they happen too quickly [77]. On the other hand, well-timed degradation that allows the biomaterial to be replaced by extracellular matrix (ECM) deposition can result in the axon bundles surviving the biomaterial's entire breakdown. 
Changing the mechanical qualities of the scaffold could affect wound healing and the immunological response [18], [19]. Category of structural integrity in spinal scaffold could be divided into three groups: Non-degradable, degradable, and electrically active materials.

a) Non-degradable scaffolds are comprised of synthetic materials that allow for consistent and precise production. They also necessitate a simpler design due to the absence of concerns such as degradation rate control and degradation product toxicity. The permanent implantation of a non-degradable channel, on the other hand, increases the risk of inflammation and can lead to nerve compression overtime, necessitating a second surgery to remove the material [43]. Non-degradable materials are usually often noncell adherent by nature, restricting their use in more advanced channel designs that requiring cell transplantation. Despite these drawbacks, non-degradable channels' simple design and construction have made them particularly valuable in basic studies of CNS nerve healing, and their usage in vitro and in vivo have sped up experimental progress [18], [19].

b) Degradable channels eliminate the requirement for either a permanent implant or a second procedure to remove a non-degradable material. Since they deteriorate when the nerve regenerates, they also pose a lower danger of nerve compression. Natural or synthetic materials can be used to make degradable channels, however, natural sources account for the vast majority of degradable channels. Because of batch-to-batch variability, materials derived from natural sources might cause challenges with nerve guide consistency and control [43], [78]. Furthermore, many naturally obtained materials are difficult to purify, and insufficient purification might cause the implant to activate the immune system [79]. Degradable channels additionally necessitate more sophisticated designs due to the fact that their degradation products must be harmless, and their degradation rates must be adjusted to match the regeneration rate. Natural materials have a higher affinity for neurons and glial cells, making them ideal candidates for more "biointeractive" designs [80].

c) The usage of electrically active materials is a second design method being investigated. Electrically charged elements in the ECM are thought to create electric fields that function as signals to stimulate and regulate growth, remodeling, and protein adsorption when tissues mature or regenerate [81]. Neurite extension is boosted by electrically active materials in vitro, and growth directionality may be modulated on them. The functional recovery of motor and CNS nerves has been found to benefit by in vivo electrical stimulation [82]. The opportunity to give localized electrical stimulation at an injury area while also providing a physical surface for regeneration is offered by constructing nerve guidance channels with electrically active materials. Polymers featuring a quasi-permanent surface charge (electrets), polymers that create an electric charge when mechanical stress is applied (piezoelectrics), and electrically conducting polymers are the three primary categories of electrically active biomaterials under research [43].

\section{Scaffolding strategy in principle of diamond concept}

Scaffolding material basically divided into two major categories, natural biomaterials and synthetic biomaterials. Natural biomaterials are extracted from natural sources such as living creature. Mostly natural material discovered by its similarity to human tissue structure and composition. Those natural materials for scaffolding are agarose, alginate, collagen, chitosan, fibrin, and hyaluronic acid (HA). Meanwhile, synthetic materials are extracted and created from chemical structure with various modifications. Synthetic materials are proposed as biomaterials for scaffolding due to its visibility for modification. Those synthetic materials are methylcellulose, nitrocellulose, poly(ethylene glycol) (PEG), poly(2-hydroxyethyl methacrylate) (pHEMA), and poly(lactic-co-glycolic acid) (PLGA). To implement scaffolding strategy for treating spinal cord, ideally every aspect of the diamond concept is fulfilled. In the following picture, we represent illustration of scaffolding strategy by considering every aspect of diamond concept in the following Figure 1 and Figure 2. We compare each diamond concept component for each natural and synthetic material on the following Table 7 and 8 . We illustrate the implementation potential of diamond concept during spinal cord injury process in the Figure 3.

\section{Agarose}

When implanted in vivo, agarose is a linear polysaccharide that causes no major adverse reactions [19]. It can be tuned to match the mechanical characteristics of the spinal cord and it is stable for long periods of time once implanted [83]. Before implantation, it can be paired with a growth factor (such as brainderived neurotrophic factor or NT-3), ECM (such as fibrin or collagen), or suitable cells to enhance neurite development inside an agarose scaffold or across the lumen of an agarose conduit [19], [84].

\section{Alginate}

Brown seaweed yields alginate, a watersoluble polysaccharide. It is made up of 1-4 connected 
a-L-guluronic and b-D-mannuronic acid residues that crosslink when multivalent cations are present [85]. In models of $\mathrm{SCl}$, alginate has been demonstrated to increase neuronal sprouting while lowering inhibitory signals post-damage [19]. Gelation ready alginate creates 3D structures such as fibers, capillaries, and microspheres, which may be utilized as biosensors and bioactuators in a variety of biomedical applications such as drug delivery and wound healing. Alginate hydrogels have had a big influence on regenerative medicine and tissue engineering because of their high water content, which allows them to imitate the mechanical qualities of actual tissues [86].

\section{Collagen}

Collagen, the most abundant ECM protein in mammals, has been widely researched as a scaffold to stimulate axonal regeneration in a rodent following $\mathrm{SCl}$. Collagen has integrin binding sites that help neuronal cells migrate and expand [87]. Neurite growth is directed by gradients of a laminin mimetic peptide inserted into type I collagen scaffolds, according to recent in vitro research [88]. Several investigations have shown that collagen-based scaffolds have good prospects as cell transporters and bridge materials in a variety of CNS experimental animal models [41], [89], [90]. The implantation has been shown to be safe and to provide considerable healing in $\mathrm{SCl}$ by boosting neurons and decreasing the development of glial scar formation. Clinical trial on collagen scaffold in treating acute $\mathrm{SCl}$ has shown to be safe and potential strategy. It delivered improvement of patient motor, sensory, and activities of daily living score improvement [41].

\section{Chitosan}

Chitosan is made from chitin that was alkaline $\mathrm{N}$-deacetylated and is biocompatible, biodegradable, and non-toxic. Chitosan may be modified to create scaffolds with continuous channels that might be utilized to bridge a CNS damage gap [19], [91]. The degree of acetylation of chitosan, on the other hand, can affect cells' capacity to attach and move on the substrate surface. Because of its unique and attractive features such as cytocompatibility, biodegradability, and non-toxicity, chitosan-based materials and derivatives have gotten a lot of interest in tissue engineering [92]. They have been studied extensively for epithelial and soft-tissue regeneration, and their benefits include the preservation of cellular phenotypes, increased activity of bound bioactive molecules, and promotion of tissuespecific ECM formation [93].

\section{Fibrin}

Fibrin, because of its involvement in wound healing and tissue rebuilding, is a promising biomaterial scaffold for nerve regeneration. Fibrin has also been thoroughly investigated as a biomaterial [19], [94]. It has been found to stimulate axonal regeneration and cell migration when used as a matrix to fill nerve guide tubes implanted following sciatic nerve damage in neural tissue engineering. During healing, fibrin generates a temporary ECM network that has distinct impacts on cells' capacity to grow and move for spontaneous tissue repair [95]. Fibrin has also reported in many studies to be suitable as growth factor or stem cell delivery media [96], [97]. Fibrin forms a loose non-covalent mesh after being split by active thrombin, which is stabilized by covalent bonds created by the transglutaminase Factor XIIla. Two arg-gly-asp (RGD) sites are found in human fibrinogen, which give integrin binding sites that may aid cell migration or axon development [98].

\section{$H A$}

$\mathrm{HA}$ is a long-chain polysaccharide that is a key component of the ECM and may be enzyme into various molecular weights in vivo [99]. High-molecular-weight $\mathrm{HA}$ and low-molecular-weight HA have fundamentally distinct physiological activities. Through interactions with inflammatory cells and ECM proteins, highmolecular-weight HA can attenuate the inflammatory response and fibrous scar formation following SCl. Angiogenesis can be enhanced by low-molecularweight HA (125-175 kDa). However, because of its low cell adherence, HA is frequently modified or combined with other compounds [100], [101] (Khaing et al., 2011). Because HA is extremely biocompatible, immune and chemically inert, and non-toxic, it eliminates the risk of brain tissue rejection. The use of $\mathrm{HA}$, one of the key components of the ECM in CNS tissue and the niche of neural stem cells (NSCs), is a promising choice for improving NSC longevity and differentiation. Encapsulation of human ESC-derived NSCs (hESC-NS) in HA-based hydrogel has been shown to promote differentiation of these cells into oligodendrocytes and enhance locomotor activity [99]. It also reported that HA has a neuroprotective capability by decreasing the magnitude of secondary injury presented in animal model of SCI [102]

Table 7: Comparison of natural biomaterials by diamond concept analysis

\begin{tabular}{llllll}
\hline $\begin{array}{l}\text { Natural } \\
\text { material }\end{array}$ & $\begin{array}{l}\text { Cellular } \\
\text { platform }\end{array}$ & $\begin{array}{l}\text { Cellular } \\
\text { inductivity }\end{array}$ & $\begin{array}{l}\text { Cellular } \\
\text { conductivity }\end{array}$ & $\begin{array}{l}\text { Structural } \\
\text { integrity }\end{array}$ & Reference \\
\hline Agarose & + & +++ & N/A & ++ & [19], [83], [84] \\
Alginate & $\mathrm{N} / \mathrm{A}$ & ++ & $\mathrm{N} / \mathrm{A}$ & ++ & {$[19],[85],[86]$} \\
Collagen & +++ & +++ & ++ & ++ & {$[41],[87],[88],[89],[90]$} \\
Chitosan & ++ & ++ & ++ & ++ & [19], [91], [92], [93] \\
Fibrin & + & ++ & ++ & $\mathrm{N} / \mathrm{A}$ & [19], [94], [95], [96], [97], [98] \\
$\begin{array}{ll}\text { Hyaluronic } \\
\text { acid }\end{array}$ & ++ & ++ & + & $\mathrm{N} / \mathrm{A}$ & [99], [100], [101], [102] \\
\hline +++: Strong; ++: Moderate; +: Weak, +/-: Considerable benefit, N/A: No available report.
\end{tabular}

\section{Methylcellulose}

Another polysaccharide, methylcellulose, may be dissolved in cold water, and when the temperature 


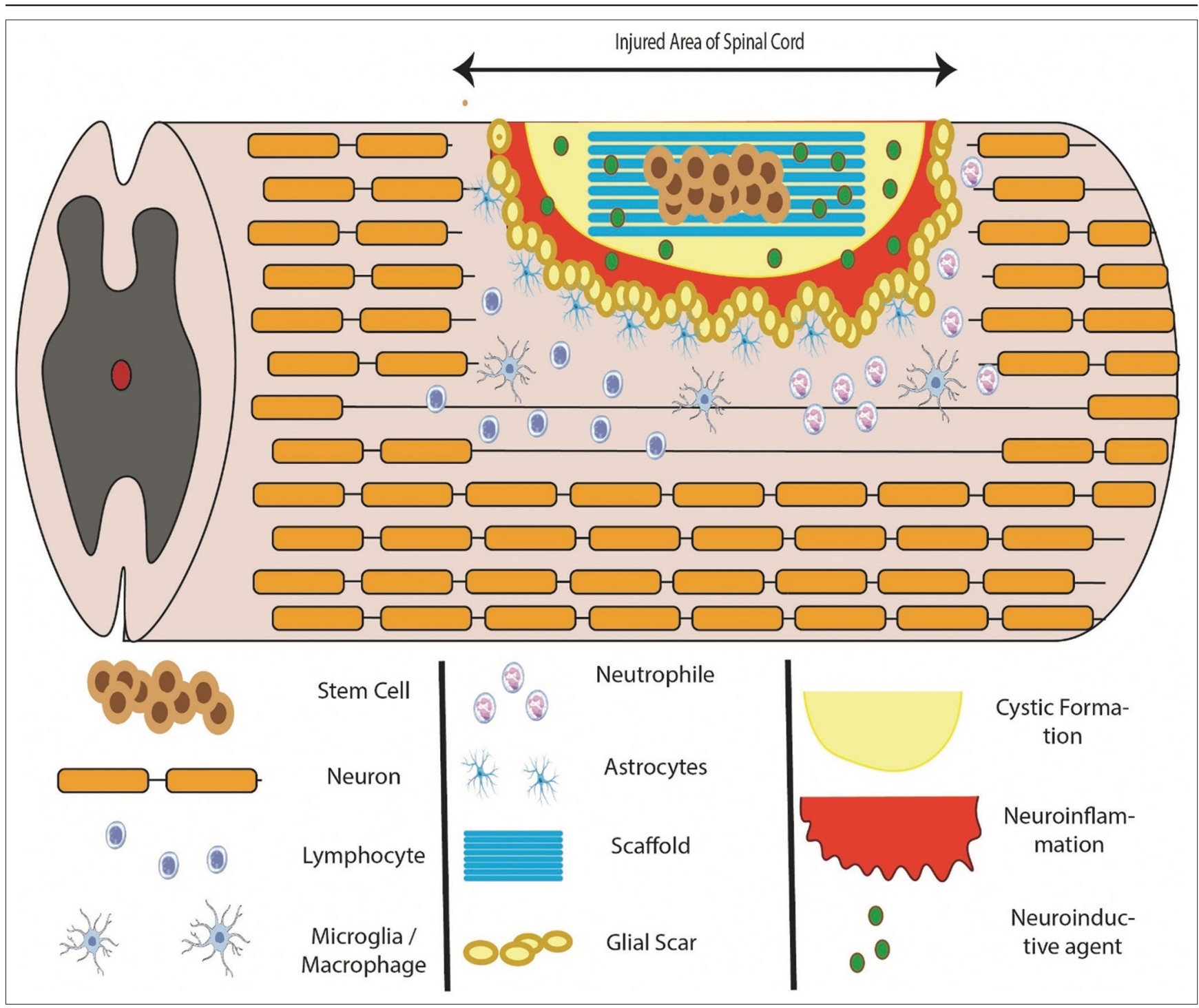

Figure 1: Illustration of diamond concept implementation for spinal cord injury

of the fluid rises, hydrogen bonds between the polymer and the surrounding solvent break and hydrophobic junctions develop, resulting in a solid gel [19]. Because dissolved methylcellulose may be injected as a fluid at ambient temperature and subsequently solidify into semisolid gels at body temperature, it can be used as a medication delivery method to provide growth factors to a damaged spinal cord [103], [104].

\section{Nitrocellulose}

In Southern and Northern blots, nitrocellulose has long been involved as a research tool to immobilize nucleic acids. The non-specific adhesion of proteins is facilitated by the surface charge of nitrocellulose. In the developing rat spinal cord, untreated strips of nitrocellulose support minimal axonal development, but pre-treatment with nerve growth factor (NGF)

\begin{tabular}{|c|c|c|}
\hline $\begin{array}{c}\text { Stem cell transplantation to provide } \\
\text { cellular platfrom requierement } \\
\text { brug / Neuroinductive agent delivery } \\
\text { byflammatory state and boost regen- } \\
\text { eration process }\end{array}$ & $\begin{array}{c}\text { Scaffold material which determine } \\
\text { Neuroconductivity for cell } \\
\text { adherence }\end{array}$ \\
$\begin{array}{c}\text { Scaffold degradation to calculate } \\
\text { structural intergrity during } \\
\text { regeneration and healing process }\end{array}$ \\
\hline
\end{tabular}

Figure 2: Illustration of strategy in diamond concept for spinal cord injury 


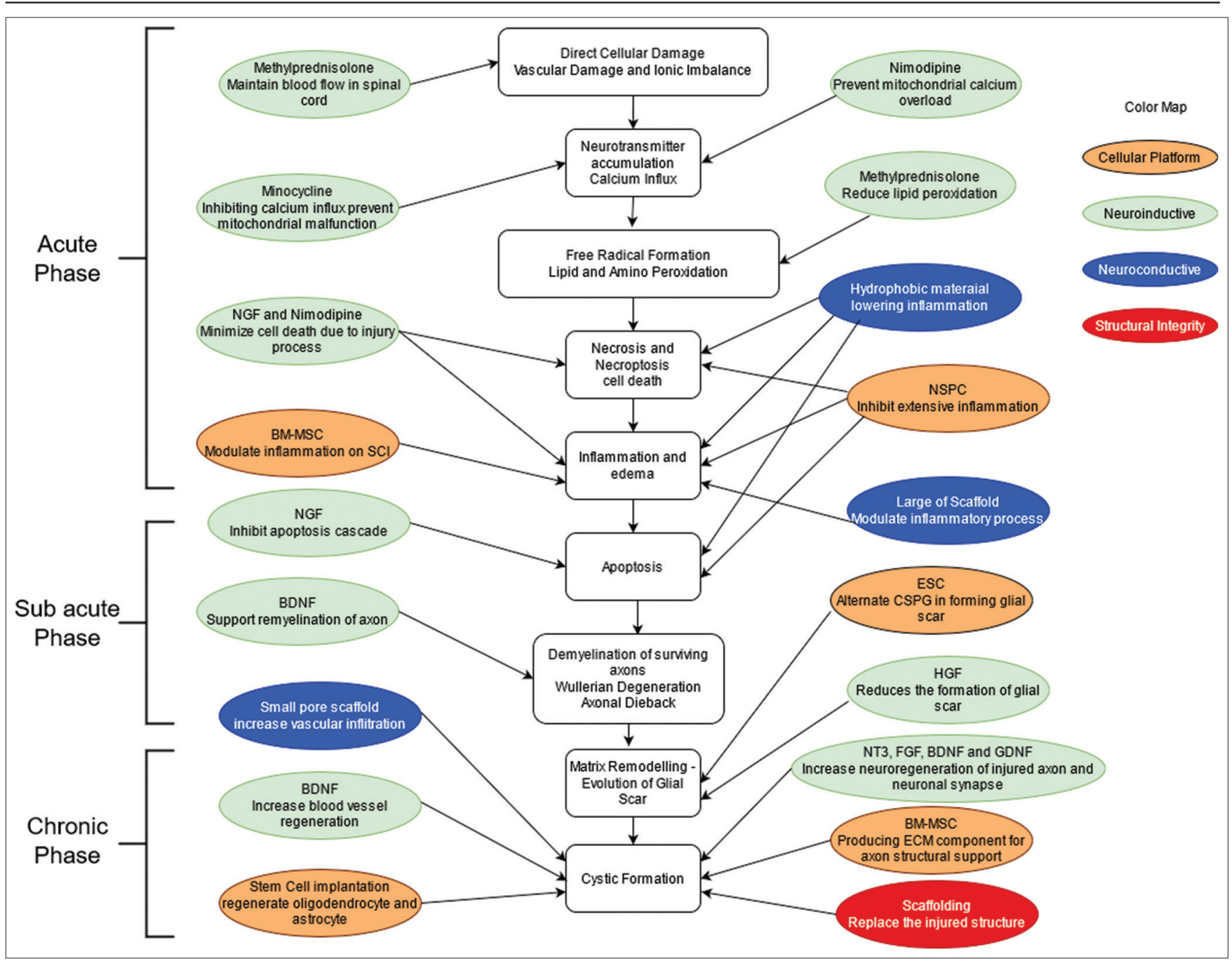

Figure 3: Treatment of spinal cord injury by diamond concept

promotes development across the implants. Thus, while nitrocellulose alone may not be effective as a scaffold for $\mathrm{SCl}$, it has showed some potential when combined with other therapies [19], [103].

\section{PEG}

PEG or poly(ethylene-oxide) is a low-toxicity hydrophilic polymer that has been employed in a range of applications, including clinical drug delivery, cosmetics, and cell culture [19]. PEG can be fabricated into a degradable hydrogel and used as vehicle for the delivery of therapeutic agents for tissue engineering applications [105]. PEG also appears to have a neuroprotective effect through reducing oxidative stress after SCI through direct contact with mitochondria [106]. When administered systemically after $\mathrm{SCl}$ in a mouse, block copolymers containing PEG have also been demonstrated to improve functional recovery [107].

\section{PHEMA}

pHEMA is a non-degradable, biocompatible, and non-toxic contact lens material. The hydrogel is made up of cross-linked networks of hydrophilic copolymers that expand in water and serve as a substrate for cell adhesion and growth as well as small-molecule transport [19]. pHEMA conduits may be molded into tubes and used as nerve guiding conduits in neural tissue engineering applications [103]. A previous study found that implanting induced pluripotent stem cell-derived neural progenitor in pHEMA polymer into chronic SCI improved material integration, decreased cavitation, and maintained stem cell survival, but did not result in a statistically significant increase in locomotor recovery [108].

\section{PLGA}

PLGA is a biocompatible and biodegradable synthetic copolymer comprising polylactic acid and polyglycolic acid. The ratio of polylactic acid and polyglycolic acid may be changed to influence the copolymer's breakdown rate [109]. The rat spinal cord was entirely transected, and neural conduits made of PLGA were transplanted. In the channels of the neural conduits, axonal regeneration has been documented [110]. The breakdown of PLGA, however, 
created glycolic and lactic acids, which decreased the local $\mathrm{pH}$ and hampered the tissue repair process [111].

Table 8: Comparison of synthetic biomaterials by diamond concept analysis

\begin{tabular}{llllll}
\hline $\begin{array}{l}\text { Synthetic } \\
\text { Material }\end{array}$ & $\begin{array}{l}\text { Cellular } \\
\text { platform }\end{array}$ & $\begin{array}{l}\text { Cellular } \\
\text { inductivity }\end{array}$ & $\begin{array}{l}\text { Cellular } \\
\text { conductivity }\end{array}$ & $\begin{array}{l}\text { Structural } \\
\text { integrity }\end{array}$ & Reference \\
\hline Methylcellulose & N/A & + & $\mathrm{N} / \mathrm{A}$ & $\mathrm{N} / \mathrm{A}$ & {$[19],[103],[104]$} \\
Nitrocellulose & $\mathrm{N} / \mathrm{A}$ & + & + & $\mathrm{N} / \mathrm{A}$ & {$[19],[103]$} \\
PEG & ++ & ++ & ++ & $\mathrm{N} / \mathrm{A}$ & {$[19],[105],[106],[107]$} \\
PHEMA & ++ & + & ++ & $\mathrm{N} / \mathrm{A}$ & {$[19],[103],[108]$} \\
PLGA & $\mathrm{N} / \mathrm{A}$ & $\mathrm{N} / \mathrm{A}$ & ++ & $+/-$ & {$[109],[110],[111]$} \\
\hline
\end{tabular}

+++: Strong; ++: Moderate; +: Weak, +l-: Considerable benefit, N/A: No available report

\section{Conclusion}

Diamond concept approach to understand each progressive step of $\mathrm{SCl}$ pathophysiology seems to be promising to get a better comprehensive strategy of treatment. Neuroinflammation, glial scar formation, and inhibiting environment of axonal regeneration seem to be the main problem of $\mathrm{SCl}$. To overcome those problems, perspective of $\mathrm{SCl}$ condition in the terms of cellular platform, inductivity, conductivity, and structural integrity disruption brings a more comprehensive idea of intervention. Implementation of scaffolding in the treatment strategy for $\mathrm{SCl}$ ideally fulfills all of the diamond concept requirement instead of partially deployed. This concept of implantation is expected to give a better outcome for $\mathrm{SCl}$ patient.

\section{References}

1. Alizadeh A, Dyck SM, Karimi-Abdolrezaee S. Traumatic spinal cord injury: An overview of pathophysiology, models and acute injury mechanisms. Front Neurol. 2019;10:282. http://doi. org/10.3389/fneur.2019.00282/full

\section{PMid:30967837}

2. Dumont RJ, Okonkwo DO, Verma S, Hurlbert RJ, Boulos PT, Ellegala DB, et al. Acute spinal cord injury, Part I: Pathophysiologic mechanisms. Clin Neuropharmacol. 2001;24(5):254-64. http:// doi.org/10.1097/00002826-200109000-00002

PMid: 11586110

3. Thompson C, Mutch J, Parent S, Mac-Thiong JM. The changing demographics of traumatic spinal cord injury: An 11-year study of 831 patients. J Spinal Cord Med. 2015;38(2):214-23. http:/ doi.org/10.1179/2045772314Y.0000000233

\section{PMid:25096709}

4. Ma VY, Chan L, Carruthers KJ. Incidence, prevalence, costs, and impact on disability of common conditions requiring rehabilitation in the united states: Stroke, spinal cord injury, traumatic brain injury, multiple sclerosis, osteoarthritis, rheumatoid arthritis, limb loss, and back pa. Arch Phys Med Rehabil. 2014;95(5):986-95. e1. http://doi.org/10.1016/j.apmr.2013.10.032 PMid:24462839

5. Fehlings M, Singh A, Tetreault L, Kalsi-Ryan S, Nouri A. Global prevalence and incidence of traumatic spinal cord injury. Clin Epidemiol. 2014;6:309-31. http://doi.org/10.2147/CLEP.S68889

\section{PMid:25278785}

6. Varma AK, Das A, Wallace G, Barry J, Vertegel AA, Ray SK, et al Spinal cord injury: A review of current therapy, future treatments, and basic science frontiers. Neurochem Res. 2013;38(5):895905. http://doi.org/10.1007/s11064-013-0991-6 PMid:23462880

7. Alexander JK, Popovich PG. Neuroinflammation in Spinal Cord Injury: Therapeutic Targets for Neuroprotection and Regeneration; 2009. p. 125-37. Available from: https:// linkinghub.elsevier.com/retrieve/pii/S0079612309175088. [Last accessed 2021 Aug 15].

8. Andrzejowski P, Giannoudis PV. The "diamond concept" for long bone non-union management. J Orthop Traumatol. 2019;20(1):21. http://doi.org/10.1186/s10195-019-0528-0 PMid:30976944

9. Giannoudis PV, Einhorn TA, Marsh D. Fracture healing: The diamond concept. Injury. 2007;38(Suppl 4):S3-6. http://doi. org/10.1016/s0020-1383(08)70003-2

PMid:18224731

10. Mironov AA, Beznoussenko GV. Models of intracellular transport: Pros and cons. Front Cell Dev Biol. 2019;7:146. http:// doi.org/10.3389/fcell.2019.00146 PMid:31440506

11. Dias C, Nylandsted J. Plasma membrane integrity in health and disease: Significance and therapeutic potential. Cell Discov. 2021;7(1):4. http://doi.org/10.1038/s41421-020-00233-2 PMid:33462191

12. Sherwood L. Human Physiology: From Cells to Systems. $8^{\text {th }}$ ed. Belmont, CA : Brooks/Cole, Cengage Learning; 2013.

13. Aloe L, Rocco M, Bianchi P, Manni L. Nerve growth factor: From the early discoveries to the potential clinical use. J Transl Med. 2012;10(1):239. http://doi.org/10.1186/1479-5876-10-239 PMid:23190582

14. Becher B, Spath S, Goverman J. Cytokine networks in neuroinflammation. Nat Rev Immunol. 2017;17(1):49-59. http:// doi.org/10.1038/nri.2016.123 PMid:27916979

15. Kusindarta DL, Wihadmadyatami $\mathrm{H}$. The role of extracellular matrix in tissue regeneration. In: Tissue Regeneration. London: InTech; 2018

16. Even-Ram S, Artym V, Yamada KM. Matrix control of stem cell fate. Cell. 2006;126(4):645-7. http://doi.org/10.1016/j. cell.2006.08.008 PMid:16923382

17. Howard D, Buttery LD, Shakesheff KM, Roberts SJ Tissue engineering: Strategies, stem cells and scaffolds. J Anat. 2008;213(1):66-72. http://doi. org/10.1111/j.1469-7580.2008.00878.x

PMid: 18422523

18. Qu W, Chen B, Shu W, Tian H, Ou X, Zhang X, et al. Polymerbased scaffold strategies for spinal cord repair and regeneration. Front Bioeng Biotechnol. 2020;8:590549. http://doi.org/10.3389/ fbioe. 2020.590549

PMid:33117788

19. Sakiyama-Elbert S, Johnson PJ, Hodgetts SI, Plant GW, Harvey AR. Scaffolds to promote spinal cord regeneration. Handb Clin Neurol. 2012;109:575594. http://doi.org/10.1016/ B978-0-444-52137-8.00036-X PMid:23098738

20. Orr MB, Gensel JC. Spinal cord injury scarring and inflammation: Therapies targeting glial and inflammatory responses. Neurotherapeutics. 2018;15(3):541-53. http://doi.org/10.1007/ s13311-018-0631-6

PMid:29717413 
21. Anwar MA, Al Shehabi TS, Eid AH. Inflammogenesis of secondary spinal cord injury. Front Cell Neurosci. 2016;10:98. http://doi.org/10.3389/fncel.2016.00098

PMid:27147970

22. Tator $\mathrm{CH}$, Koyanagi I. Vascular mechanisms in the pathophysiology of human spinal cord injury. J Neurosurg. 1997;86(3):483-92. http://doi.org/10.3171/jns.1997.86.3.0483 PMid:9046306

23. Pivovarova NB, Andrews SB. Calcium-dependent mitochondrial function and dysfunction in neurons. FEBS J. 2010;277(18):362236. http://doi.org/10.1111/j.1742-4658.2010.07754.x PMid:20659161

24. Duchen MR. Mitochondria, calcium-dependent neuronal death and neurodegenerative disease. Pflügers Arch. 2012;464(1):11121. http://doi.org/10.1007/s00424-012-1112-0 PMid:22615071

25. Song W, Song G, Zhao C, Li X, Pei X, Zhao W, et al. Testing pathological variation of white matter tract in adult rats after severe spinal cord injury with MRI. Biomed Res Int. 2018;2018:1-13.

26. Dunai Z, Bauer PI, Mihalik R. Necroptosis: Biochemical, physiological and pathological aspects. Pathol Oncol Res. 2011;17(4):791-800. http://doi.org/10.1007/s12253-011-9433-4 PMid:21773880

27. Liu S, Li Y, Choi HMC, Sarkar C, Koh EY, Wu J, et al. Lysosomal damage after spinal cord injury causes accumulation of RIPK1 and RIPK3 proteins and potentiation of necroptosis. Cell Death Dis. 2018;9(5):476. http://doi.org/10.1038/s41419-018-0469-1 PMid:29686269

28. Oyinbo CA. Secondary injury mechanisms in traumatic spinal cord injury: A nugget of this multiply cascade. Acta Neurobiol Exp (Wars). 2011;71(2):281-99. PMid:21731081

29. Zhang $\mathrm{N}$, Yin $\mathrm{Y}, \mathrm{Xu}$ SJ, Wu YP, Chen WS. Inflammation and apoptosis in spinal cord injury. Indian $\mathrm{J}$ Med Res. 2012;135(3):287-96. PMid:22561613

30. Elmore S. Apoptosis: A review of programmed cell death. Toxicol Pathol. 2007;35(4):495-516. http://doi. org/10.1080/01926230701320337

PMid:17562483

31. Donnelly DJ, Popovich PG. Inflammation and its role in neuroprotection, axonal regeneration and functional recovery after spinal cord injury. Exp Neurol. 2008;209(2):378-88. http:// doi.org/10.1016/j.expneurol.2007.06.009

PMid:17662717

32. Okada S. The pathophysiological role of acute inflammation after spinal cord injury. Inflamm Regen. 2016;36(1):20.

33. Ankeny DP, Lucin KM, Sanders VM, McGaughy VM, Popovich PG. Spinal cord injury triggers systemic autoimmunity: Evidence for chronic B lymphocyte activation and lupus-like autoantibody synthesis. J Neurochem. 2006;99(4):1073-87. http://doi. org/10.1111/j.1471-4159.2006.04147.x PMid:17081140

34. Soderblom C, Luo X, Blumenthal E, Bray E, Lyapichev K, Ramos J, et al. Perivascular fibroblasts form the fibrotic scar after contusive spinal cord injury. J Neurosci. 2013;33(34):13882-7. http://doi.org/10.1523/JNEUROSCI.2524-13.2013 PMid:23966707

35. Silver J. The glial scar is more than just astrocytes. Exp Neurol. 2016;286:147-9. http://doi.org/10.1016/j.expneurol.2016.06.018 PMid:27328838

36. Yang T, Dai Y, Chen G, Cui S. Dissecting the dual role of the glial scar and scar-forming astrocytes in spinal cord injury. Front Cell
Neurosci. 2020;14:78. http://doi.org/10.3389/fncel.2020.00078 PMid:32317938

37. Galtrey CM, Fawcett JW. The role of chondroitin sulfate proteoglycans in regeneration and plasticity in the central nervous system. Brain Res Rev. 2007;54(1):1-18. http://doi. org/10.1016/j.brainresrev.2006.09.006

PMid:17222456

38. Fehlings MG, Tetreault LA, Wilson JR, Kwon BK, Burns AS, Martin AR, et al. A clinical practice guideline for the management of acute spinal cord injury: Introduction, rationale, and scope. Glob Spine J. 2017;7 Suppl 3:84S-94. http://doi. org/10.1177/2192568217703387

PMid:29164036

39. Bowers C, Kundu B, Hawryluk GJ. Methylprednisolone for acute spinal cord injury: An increasingly philosophical debate. Neural Regen Res. 2016;11(6):882-5. http://doi. org/10.4103/1673-5374.184450

\section{PMid:27482201}

40. Zhao $\mathrm{Y}$, Tang F, Xiao Z, Han G, Wang N, Yin N, et al Clinical study of neuroregen scaffold combined with human mesenchymal stem cells for the repair of chronic complete spinal cord injury. Cell Transplant. 2017;26(5):891-900. http:// doi.org/10.3727/096368917X695038

PMid:28185615

41. Deng WS, Ma K, Liang B, Liu XY, Xu HY, Zhang J, et al. Collagen scaffold combined with human umbilical cord-mesenchymal stem cells transplantation for acute complete spinal cord injury. Neural Regen Res. 2020;15(9):1686-700. http://doi. org/10.4103/1673-5374.276340

PMid:32209773

42. Kim KD, Lee KS, Coric D, Chang JJ, Harrop JS, Theodore N, et al. A study of probable benefit of a bioresorbable polymer scaffold for safety and neurological recovery in patients with complete thoracic spinal cord injury: 6-month results from the INSPIRE study. J Neurosurg Spine. 2021;5:1-10. http://doi. org/10.3171/2020.8.SPINE191507

PMid:33545674

43. Straley KS, Foo CWP, Heilshorn SC. Biomaterial Design Strategies for the Treatment of Spinal Cord Injuries. J Neurotrauma. 2010;27(1):1-19. http://doi.org/10.1089/ neu.2009.0948

PMid:19698073

44. Domingues HS, Portugal CC, Socodato R, Relvas JB. Oligodendrocyte, astrocyte, and microglia crosstalk in myelin development, damage, and repair. Front Cell Dev Biol. 2016;4:71. http://doi.org/10.3389/fcell.2016.00071 PMid:27551677

45. Wang H, Liu X, Li R, Zhang P, Chu Z, Wang C, et al. Effect of glial cells on remyelination after spinal cord injury. Neural Regen Res. 2017;12(10):1724-32. http://doi.org/10.4103/1673-5374.217354 PMid:29171439

46. Gao L, Peng Y, Xu W, He P, Li T, Lu X, et al. Progress in stem cell therapy for spinal cord injury. Stem Cells Int. 2020;2020:2853650. http://doi.org/10.1155/2020/2853650 PMid:33204276

47. Khan FA, Almohazey D, Alomari M, Almofty SA. Isolation, culture, and functional characterization of human embryonic stem cells: Current trends and challenges. Stem Cells Int 2018;2018:1429351. http://doi.org/10.1155/2018/1429351 PMid:30254679

48. Adeeb N, Deep A, Hose N, Rezaei M, Fard SA, Tubbs RS et al. Stem cell therapy for spinal cord injury: The use of oligodendrocytes and motor neurons derived from human embryonic stem cells. Transl Res Anat. 2015;1:17-24. 
49. Huang L, Fu C, Xiong F, He C, Wei Q. Stem cell therapy for spinal cord injury. Cell Transplant. 2021;30:096368972198926. http://doi.org/10.1177/0963689721989266

\section{PMid:33559479}

50. Gazdic M, Volarevic V, Harrell C, Fellabaum C, Jovicic N Arsenijevic N, et al. Stem cells therapy for spinal cord injury. Int J Mol Sci. 2018;19(4):1039. PMid:29601528

51. Shroff G, Gupta R. Human embryonic stem cells in the treatment of patients with spinal cord injury. Ann Neurosci. 2015;22(4):20816. http://doi.org/10.5214/ans.0972.7531.220404 PMid:26526627

52. Shroff G. Human embryonic stem cell therapy in chronic spinal cord injury: A retrospective study. Clin TransI Sci. 2016;9(3):16875. http://doi.org/10.1111/cts.12394 PMid:27144379

53. Dominici M, Le Blanc K, Mueller I, Slaper-Cortenbach I, Marini F, Krause DS, et al. Minimal criteria for defining multipotent mesenchymal stromal cells. The international society for cellular therapy position statement. Cytotherapy. 2006;8(4):315-7. http://doi.org/10.1080/14653240600855905 PMid:16923606

54. Dasari VR. Mesenchymal stem cells in the treatment of spinal cord injuries: A review. World J Stem Cells. 2014;6(2):120-33. http://doi.org/10.4252/wjsc.v6.i2.120 PMid:24772239

55. Ulndreaj A, Chio JC, Ahuja CS, Fehlings MG. Modulating the immune response in spinal cord injury. Expert Rev Neurother. 2016;16(10):1127-9. http://doi.org/10.1080/14737175.2016.120 7532

\section{PMid:27352883}

56. Trivedi A, Olivas AD, Noble-Haeusslein LJ. Inflammation and spinal cord injury: Infiltrating leukocytes as determinants of injury and repair processes. Clin Neurosci Res. 2006;6(5):28392. http://doi.org/10.1016/j.cnr.2006.09.007 PMid:18059979

57. Neirinckx V, Coste C, Franzen R, Gothot A, Rogister B, Wislet S. Neutrophil contribution to spinal cord injury and repair. J Neuroinflammation. 2014;11(1):150. http://doi.org/10.1186/ s12974-014-0150-2 PMid:25163400

58. Lee SM, Rosen S, Weinstein P, van Rooijen N, NobleHaeusslein LJ. Prevention of both neutrophil and monocyte recruitment promotes recovery after spinal cord injury. J Neurotrauma. 2011;28(9):1893-907. http://doi.org/10.1089/ neu.2011.1860

PMid:21657851

59. Ren $Y$, Young W. Managing inflammation after spinal cord injury through manipulation of macrophage function. Neural Plast. 2013;2013:945034. http://doi.org/10.1155/2013/945034 PMid:24288627

60. Ren $\mathrm{H}$, Chen X, Tian M, Zhou J, Ouyang $\mathrm{H}$, Zhang Z. Regulation of inflammatory cytokines for spinal cord injury repair through local delivery of therapeutic agents. Adv Sci. 2018;5(11):1800529. http://doi.org/10.1002/advs.201800529 PMid:30479916

61. Marcantoni M, Fuchs A, Löw P, Bartsch D, Kiehn O, Bellardita C Early delivery and prolonged treatment with nimodipine prevents the development of spasticity after spinal cord injury in mice. Sci TransI Med. 2020;12(539):eaay0167. http://doi.org/10.1126/ scitransImed.aay0167 PMid:32295897

62. Gwak YS, Hulsebosch CE. GABA and central neuropathic pain following spinal cord injury. Neuropharmacology.
2011;60(5):799-808.

neuropharm.2010.12.030

PMid:21216257

63. Shultz R, Zhong Y. Minocycline targets multiple secondary injury mechanisms in traumatic spinal cord injury. Neural Regen Res. 2017;12(5):702-13. http://doi.org/10.4103/1673-5374.206633 PMid:28616020

64. Keefe K, Sheikh I, Smith G. Targeting neurotrophins to specific populations of neurons: NGF, BDNF, and NT-3 and their relevance for treatment of spinal cord injury. Int J Mol Sci. 2017;18(3):548. http://doi.org/10.3390/ijms18030548 PMid:28273811

65. Zhang $\mathrm{H}$, Wu F, Kong $\mathrm{X}$, Yang $\mathrm{J}$, Chen $\mathrm{H}$, Deng $\mathrm{L}$, et al. Nerve growth factor improves functional recovery by inhibiting endoplasmic reticulum stress-induced neuronal apoptosis in rats with spinal cord injury. J TransI Med. 2014;12(1):130. http:// doi.org/10.1186/1479-5876-12-130

PMid:24884850

66. Donovan J, Kirshblum S. Clinical trials in traumatic spina cord injury. Neurotherapeutics. 2018;15(3):654-68. http://doi. org/10.1007/s13311-018-0632-5

PMid:29736858

67. Xiao Z, Zhao Y, Chen B, Dai J. Scaffolds for spinal cord injury repair: From proof of concept to first in-human studies and clinical trials. In: Handbook of Innovations in Central Nervous System Regenerative Medicine. Amsterdam, Netherlands: Elsevier; 2020. p. 603-19.

68. Ko CC, Tu TH, Wu JC, Huang WC, Cheng H. Acidic fibroblast growth factor in spinal cord injury. Neurospine. 2019;16(4):72838. http://doi.org/10.14245/ns.1836216.108 PMid:30653905

69. Rosner J, Avalos P, Acosta F, Liu J, Drazin D. The potential for cellular therapy combined with growth factors in spinal cord injury. Stem Cells Int. 2012;2012:1-11.

70. Yokota K, Fehlings MG. Acidic fibroblast growth factor in spina cord injury: A potential therapy which merits further investigation. Neurospine. 2019;16(4):739-41. http://doi.org/10.14245/ ns.19edi.018 PMid:31905463

71. Zhou Y, Wang Z, Li J, Li X, Xiao J. Fibroblast growth factors in the management of spinal cord injury. $J$ Cell Mol Med. 2018;22(1):25-37. http://doi.org/10.1111/jcmm.13353 PMid:29063730

72. Ortmann S, Hellenbrand D. Glial cell line-derived neurotrophic factor as a treatment after spinal cord injury. Neural Regen Res. 2018;13(10):1733-4. http://doi.org/10.4103/1673-5374.238610 PMid:30136685

73. Yin $\mathrm{Y}, \mathrm{He} \mathrm{XT}$, Wang J, Wu RX, Xu XY, Hong $\mathrm{YL}$, et al. Pore size-mediated macrophage M1-to-M2 transition influences new vessel formation within the compartment of a scaffold. Appl Mater Today. 2020;18:100466.

74. Tylek T, Blum C, Hrynevich A, Schlegelmilch K, Schilling T, Dalton PD, et al. Precisely defined fiber scaffolds with $40 \mu \mathrm{m}$ porosity induce elongation driven M2-like polarization of human macrophages. Biofabrication. 2020;12(2):025007. http://doi. org/10.1088/1758-5090/ab5f4e

PMid:31805543

75. Cao J, Wu J, Mu J, Feng S, Gao J. The design criteria and therapeutic strategy of functional scaffolds for spinal cord injury repair. Biomater Sci. 2021;9(13):4591-606. http://doi. org/10.1039/d1bm00361e PMid:34018520

76. Eltom A, Zhong G, Muhammad A. Scaffold techniques and designs in tissue engineering functions and purposes: A review. 
Adv Mater Sci Eng. 2019;2019:1-13.

77. Zhang H, Zhou L, Zhang W. Control of scaffold degradation in tissue engineering: A review. Tissue Eng Part B Rev. 2014;20(5):492-502. http://doi.org/10.1089/ten.TEB.2013.0452 PMid:24547761

78. Shrestha B, Coykendall K, Li Y, Moon A, Priyadarshani P, Yao L. Repair of injured spinal cord using biomaterial scaffolds and stem cells. Stem Cell Res Ther. 2014;5(4):91. http://doi. org/10.1186/scrt480

PMid:25157690

79. Tabesh H, Amoabediny G, Nik NS, Heydari M, Yosefifard M, Siadat SO, et al. The role of biodegradable engineered scaffolds seeded with Schwann cells for spinal cord regeneration. Neurochem Int. 2009;54(2):73-83.

PMid:19084565

80. Pina S, Ribeiro VP, Marques CF, Maia FR, Silva TH, Reis $\mathrm{RL}$, et al. Scaffolding strategies for tissue engineering and regenerative medicine applications. Materials (Basel). 2019;12(11):1824. http://doi.org/10.3390/ma12111824 PMid:31195642

81. Seil JT, Webster TJ. Electrically active nanomaterials as improved neural tissue regeneration scaffolds. WIREs Nanomed Nanobiotechnol. 2010;2(6):635-47. http://doi.org/10.1002/ wnan.109 PMid:20730786

82. Patel N, Poo M. Orientation of neurite growth by extracellular electric fields. J Neurosci. 1982;2(4):483-96. http://doi. org/10.1523/JNEUROSCI.02-04-00483.1982 PMid:6279799

83. Balgude A. Agarose gel stiffness determines rate of $D R G$ neurite extension in 3D cultures. Biomaterials. 2001;22(10):1077-84.

84. Jain A, McKeon RJ, Brady-Kalnay SM, Bellamkonda R V. Sustained delivery of activated rho GTPases and BDNF promotes axon growth in CSPG-rich regions following spinal cord injury. PLoS One. 2011;6(1):e16135. http://doi.org/10.1371/ journal.pone.0016135 PMid:21283639

85. Augst $\mathrm{AD}$, Kong $\mathrm{HJ}$, Mooney DJ. Alginate hydrogels as biomaterials. Macromol Biosci. 2006;6(8):623-33. http://doi. org/10.1002/mabi.200600069

PMid:16881042

86. Grijalvo S, Nieto-Díaz M, Maza RM, Eritja R, Díaz DD. Alginate hydrogels as scaffolds and delivery systems to repair the damaged spinal cord. Biotechnol J. 2019;14(12):1900275. http://doi.org/10.1002/biot.201900275

PMid:31677223

87. Li X, Dai J. Bridging the gap with functional collagen scaffolds: Tuning endogenous neural stem cells for severe spinal cord injury repair. Biomater Sci. 2018;6(2):265-71.

88. Yao L, Damodaran G, Nikolskaya N, Gorman AM, WindebankA, Pandit $A$. The effect of laminin peptide gradient in enzymatically cross-linked collagen scaffolds on neurite growth. J Biomed Mater Res Part A. 2010;92:484-92. http://doi.org/10.1002/ jbm.a.32359

\section{PMid:19213056}

89. Kourgiantaki A, Tzeranis DS, Karali K, Georgelou K, Bampoula E, Psilodimitrakopoulos S, et al. Neural stem cell delivery via porous collagen scaffolds promotes neuronal differentiation and locomotion recovery in spinal cord injury. npj Regen Med. 2020;5(1):12.

90. Li JJ, Liu H, Zhu Y, Yan L, Liu R, Wang G, et al. Animal models for treating spinal cord injury using biomaterials-based tissue engineering strategies. Tissue Eng Part B Rev. 2021;2021:267. http://doi.org/10.1089/ten.TEB.2020.0267

\section{PMid:33267667}

91. Rodríguez-Vázquez M, Ramos-Zúñiga R. Chitosanhydroxyapatite scaffold for tissue engineering in experimental lumbar laminectomy and posterolateral spinal fusion in wistar rats. Asian Spine J. 2020;14(2):139-47. http://doi.org/10.31616/ asj.2019.0091

PMid:31679322

92. Rodríguez-Vázquez $M$, Vega-Ruiz $B$, Ramos-Zúñiga $R$ Saldaña-Koppel DA, Quiñones-Olvera LF. Chitosan and its potential use as a scaffold for tissue engineering in regenerative medicine. Biomed Res Int. 2015;2015:821279. http://doi. org/10.1155/2015/821279

\section{PMid:26504833}

93. Chedly J, Soares S, Montembault A, von Boxberg Y, VeronRavaille M, Mouffle C, et al. Physical chitosan microhydrogels as scaffolds for spinal cord injury restoration and axon regeneration. Biomaterials. 2017;138:91-107. http://doi. org/10.1016/j.biomaterials.2017.05.024

PMid:28554011

94. Assunção-Silva RC, Gomes ED, Sousa N, Silva NA, Salgado AJ. Hydrogels and cell based therapies in spinal cord injury regeneration. Stem Cells Int. 2015;2015:948040. https:// doi.org/10.1155/2015/948040

95. Johnson PJ, Parker SR, Sakiyama-Elbert SE. Fibrin-based tissue engineering scaffolds enhance neural fiber sprouting and delay the accumulation of reactive astrocytes at the lesion in a subacute model of spinal cord injury. J Biomed Mater Res Part A. 2010;92A(1):152-63. https://doi.org/10.1002/jbm.a.32343 PMid: 19165795

96. Griffin JM, Bradke F. Therapeutic repair for spinal cord injury: Combinatory approaches to address a multifaceted problem. EMBO Mol Med. 2020;12(3):e11505. https://doi.org/10.15252/ emmm.201911505

PMid:32090481

97. WillerthSM,FaxelTE, GottliebDI, Sakiyama-ElbertSE. Theeffects of soluble growth factors on embryonic stem cell differentiation inside of fibrin scaffolds. Stem Cells. 2007;25(9):2235-44. https://doi.org/10.1634/stemcells.2007-0111

PMid: 17585170

98. Mosesson MW. Fibrinogen and fibrin structure and functions. J Thromb Haemost. 2005;3(8):1894-904. https://doi. org/10.1111/j.1538-7836.2005.01365.x PMid: 16102057

99. Zarei-Kheirabadi M, Sadrosadat H, Mohammadshirazi A Jaberi R, Sorouri F, Khayyatan F, et al. Human embryonic stem cell-derived neural stem cells encapsulated in hyaluronic acid promotes regeneration in a contusion spinal cord injured rat. Int J Biol Macromol. 2020;148:1118-29. https://doi.org/10.1016/j. ijbiomac.2020.01.219

PMid:31982534

100. Thompson RE, Pardieck J, Smith L, Kenny P, Crawford L, Shoichet $\mathrm{M}$, et al. Effect of hyaluronic acid hydrogels containing astrocyte-derived extracellular matrix and/or V2a interneurons on histologic outcomes following spinal cord injury. Biomaterials. 2018;162:208-23. https://doi.org/10.1016/j. biomaterials.2018.02.013

PMid:29459311

101. Khaing ZZ, Milman BD, Vanscoy JE, Seidlits SK, Grill RJ, Schmidt CE. High molecular weight hyaluronic acid limits astrocyte activation and scar formation after spinal cord injury. J Neural Eng. 2011;8(4):046033. https://doi. org/10.1088/1741-2560/8/4/046033

PMid:21753237

102. Kushchayev SV, Giers MB, Eng DH, Martirosyan NL, Eschbacher JM, Mortazavi MM, et al. Hyaluronic acid scaffold 
has a neuroprotective effect in hemisection spinal cord injury. J Neurosurg Spine. 2016;25(1):114-24. https://doi. org/10.3171/2015.9.SPINE15628

PMid:26943251

103. Ghane N, Beigi MH, Labbaf S, Nasr-Esfahani MH, Kiani A Design of hydrogel-based scaffolds for the treatment of spinal cord injuries. J Mater Chem B. 2020;8(47):10712-38.

104. Shultz R, Zhong Y. Hydrogel-based local drug delivery strategies for spinal cord repair. Neural Regen Res. 2021;16(2):247-53. https://doi.org/10.4103/1673-5374.290882

PMid:32859771

105. Wang $\mathrm{Y}$, Tan $\mathrm{H}$, Hui $\mathrm{X}$. Biomaterial scaffolds in regenerative therapy of the central nervous system. Biomed Res Int. 2018;2018:7848901. https://doi.org/10.1155/2018/7848901 PMid:29805977

106. Kong X, Tang Q, Chen X, Tu Y, Sun S, Sun Z. Polyethylene glycol as a promising synthetic material for repair of spinal cord injury. Neural Regen Res. 2017;12(6):1003-8. https://doi. org/10.4103/1673-5374.208597

PMid:28761436

107. Conova L, Kubinski P, Jin Y, Vernengo J, Neuhuber B, Fischer I, et al. Injectable multifunctional scaffold for spinal cord repair.
In: Proceedings of the 2010 IEEE $36^{\text {th }}$ Annual Northeast Bioengineering Conference (NEBEC). IEEE; 2010. p. 1-2.

108. Ruzicka J, Romanyuk N, Jirakova K, Hejcl A, Janouskova O, Machova LU, et al. The effect of iPS-derived neural progenitors seeded on laminin-coated pHEMA-MOETACI hydrogel with dual porosity in a rat model of chronic spinal cord injury. Cell Transplant. 2019;28(4):400-12. https://doi.org/10.1177/0963689718823705 PMid:30654639

109. Pan Z, Ding J. Poly(lactide- co -glycolide) porous scaffolds for tissue engineering and regenerative medicine. Interface Focus. 2012;2(3):366-77. https://doi.org/10.1016/j.addr.2016.04.019 PMid:27125190

110. Wang C, Sun C, Hu Z, Huo X, Yang Y, Liu X, et al. Improved neural regeneration with olfactory ensheathing cell inoculated PLGA scaffolds in spinal cord injury adult rats. Neurosignals. 2017;25(1):1-14. https://doi.org/10.1159/000471828 PMid:28359049

111. Elmowafy EM, Tiboni M, Soliman ME. Biocompatibility, biodegradation and biomedical applications of poly(lactic acid)/ poly(lactic-co-glycolic acid) micro and nanoparticles. J Pharm Investig. 2019;49(4):347-80. 